\title{
ENTRE LITERATURAS: LEITURAS, RELEITURAS, (EM) PERSPECTIVAS
}

\author{
Andréa Figueiredo Leão Grants \\ Gizelle Kaminski Corso \\ Jair Zandoná \\ Stélio Furlan \\ Susan A. de Oliveira \\ Tanay Gonçalves Notargiacomo \\ Universidade Federal de Santa Catarina
}

O volume 18, número 1, apresenta prioritariamente investigações teóricas e críticas sobre as multiplicidades e especificidades da literatura. Para dar cor a essa proposta de encontros culturais e temáticos, a capa exibe um detalhe do painel idealizado por Martinho de Haro, em 1972, e instalado no hall do prédio da Reitoria da Universidade Federal de Santa Catarina. O detalhe do painel apresenta a figura feminina, que aparece ao plural; várias mulheres, cada qual à sua maneira, a seu modo. Porque diferentes, porque lutadoras, porque guerreiras. Desafios “atuais dos feminismos”. Prestamos, portanto, homenagem àquelas que compõem um eu, um tu, um nós, um eles e elas, subjetividades e fragmentos de vida — temas que perpassam alguns dos artigos deste número. Do mesmo modo, aproveitamos para dialogar com o tema de um evento, que é marca de nossa instituição e que se encontra em sua décima edição: "Seminário Internacional Fazendo Gênero", cujo tema abordará os feminismos e estudos de gênero e seus desafios atuais, e se realizará em setembro deste ano.

Inspirados na intensidade estética dessa obra, esperamos proporcionar aos autores e leitores todos os efeitos de aproximação e de trocas de ideias, de simbiose de sentidos e de tradução cultural a partir dos artigos que, como pedaços de retalhos, contarão cada qual, a seu modo e forma, e em sua particularidade narrativa, a história da Anuário. 
Os artigos dos professores Marcio Markendorf e Rosana Cássia Kamita, que abrem este número, foram apresentados no evento Anuário de Literatura, memórias em perspectiva, realizado em outubro de 2012, em comemoração pelo aniversário de 20 anos da Revista.

Em "O Romance brasileiro e o periodismo", Rosana Cássia Kamita conta a história particular e geral do romance brasileiro traçando o interessante percurso que vincula o gênero romance ao periodismo nos séculos XIX, XX e XXI. Marcio Markendorf abre o amplo o conjunto de reflexões sobre biografias que compõem a presente edição com seu artigo "Reflexões sobre a memória biográfica no meio audiovisual contemporâneo", retratando o percurso do relato biográfico do modelo positivista e tradicional da narrativa linear para desmontá-lo em fragmentos de imagens, aproximando o cinema da memória e observando seus efeitos de aproximação e distância com o modelo tradicional.

Navegando um pouco ao norte de nossas percepções literárias, Leandro de Azevedo Thereza nos mostra em "A construção do outro pelo outro: a categorização hierárquica do sujeito na sociedade de A letra escarlate", romance estadunidense de 1850, uma sociedade machista e religiosa que sustenta o puritanismo colonial comunitário pelo qual instituições pautavam e regulavam a vida social na Nova Inglaterra do século XVII.

A obra Dias perdidos, do mineiro Lúcio Cardoso, escrita em 1943, é discutida por Fábio Figueiredo Camargo no artigo "Autobiografia perdida" a partir da ideia de que esse seja um romance autobiográfico confrontado pelas teorias biográficas e do eu de Philippe Lejeune, Ruth Silviano Brandão, Jacques Derrida e Michel Foucault.

O artigo de Paula Renata Lucas Collares, "Autobiografia e representação de si mesmo na narrativa e crônica de António Lobo Antunes", analisa o Primeiro Livro de Crónicas e o romance Sôbolos rios que vão de António Lobo Antunes em perspectiva comparativa autobiográfica e ficcional na qual se deslocam na voz narrativa o tempo, a memória e a infância. Ainda nessa linha de tensão entre a biografia e as subjetividades emergentes, está Amaury Garcia dos Santos Neto, explorando as subjetividades alternativas, que é a forma como esse autor lê a interseção entre textos pertencentes ao espaço biográfico via Philipe Lejeune e Leonor Arfuch no personagem Francis Xavier Enderby, protagonista do romance autobiográfico Enderby por dentro, do escritor inglês Anthony Burgess.

O artigo "Reconstrução de Toledo: a intertextualidade como fator de composição no poema Toledo de Murilo Mendes”, de Nathália Macri Nahas, analisa memória e experiência no poema intertextual Toledo, de Murilo Mendes, no qual o autor lança mão de um eu lírico 
nostálgico que se compõe dos fragmentos poéticos e estéticos fortemente hispânicos de Miguel de Cervantes, Lope de Vega e El Greco.

As autoras Lydia Christina Ferreira Rezende de Medeiros e Nismária Alves David escreveram a quatro mãos o artigo "Literatura, cinema e história em Hiroshima mon amour" analisando as obras homônimas Hiroshima Mon Amour, longa-metragem realizado por Alain Resnais e Ciné-roman de Marguerite Duras, tomando como base de percepção a complementaridade entre cinema e literatura e apontam os fios que entrelaçam as duas obras que narram, cada qual a seu modo, as perdas, o amor e a humanidade no drama do protagonista que interpela o leitor/espectador pelo limite angustiante do eu frente a uma catástrofe total que foi a explosão da bomba atômica em Hiroshima.

Os autores Jandré Corrêa Batista e Michael Azevedo, adentram o gênero diário e seus meandros, analisando a obra Diário da Queda, de Michel Laub. O artigo "Em busca de elementos para uma história da literatura contemporânea: um olhar sobre a escrita de si em Diário da Queda, de Michel Laub" volta-se, como diz o título, para o problema da escrita de si a partir do outro, ou melhor, sobre a dimensão ética do outro na autodescoberta, possibilitada pela ocorrência de um "acidente" e suas consequências na vida do menino João ao qual o narrador se encontra envolvido.

Em "Não há lugar melhor que nosso lar - a casa como confinamento, personagem e espaço idealizado no filme Orgulho e Preconceito", artigo de Karina Gomes Barbosa sobre a adaptação para o cinema do romance de Jane Austen, a casa é o personagem em análise, e isso se dá pela observação do espaço doméstico elaborado na criação cinematográfica, como lugar de confinamento e afeto, elemento fundamental da vida familiar inglesa no século XIX e base do patriarcado pelo qual toda uma distinção de gênero e papéis sociais se tornou efetiva sob a dominação masculina.

Em "Estudo do multiperspectivismo narrativo de Relato de um Certo Oriente, de Milton Hatoum", Daiane Carneiro Pimentel, através da dinamização do olhar cinematográfico, procura investigar como a multiplicidade de perspectivas instaurada pela "sétima arte" foi incorporada pela literatura. No romance de Milton Hatoum, por exemplo, há cinco narradores, cujos discursos são organizados de modo semelhante à montagem invertida desenvolvida pelo cinema.

Em sentido semelhante, Janaína Guedes Milanez, em “A adaptação fílmica como procedimento de tradução intersemiótica: o caso Budapeste" propõe analisar a adaptação fílmica de Walter Carvalho e Rita Buzzar para o romance Budapeste, de Chico Buarque, a 
partir dos estudos semióticos de Charles Sanders Peirce, buscando investigar a leitura que os cineastas fazem do romance, as pistas do processo de tradução e as implicações da tipologia peirciana para uma apreciação teórico-crítica do filme.

Para fechar a edição, trazemos a tradução do texto de Philippe Chevallier, "O Baudelaire de Foucault: uma silhueta furtiva e paradoxal", realizada pelo professor da Universidade Federal de Santa Catarina, Dr. Pedro de Souza, em que é cotejada a leitura foucaultiana do poeta francês por meio da história da subjetividade.

A equipe editorial agradece aos autores pelos artigos enviados para esta edição e aos leitores que, afinal de contas, são os verdadeiros construtores desse mosaico de leituras e tessituras.

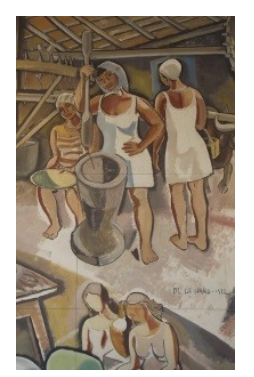

